\title{
On retranslating: a case study of Ukrainian literature in English and German translations
}

\author{
B. O. Pliushch \\ Assistant Professor, Taras Shevchenko National University of Kyiv, Ukraine \\ Corresponding author. E-mail: danapliushch@outlook.com
}

Paper received 08.11.19; Accepted for publication 21.11.19.

\section{https://doi.org/10.31174/SEND-Ph2019-212VII63-13}

\begin{abstract}
The article focuses on exploring the retranslation of the drama "Forest Song" (1911), which was written by a prominent Ukrainian author Lesya Ukrainka and is considered to be one of the examples of the classical Ukrainian literature. The new English translation (2018) by Virlana Tkacz and Wanda Phipps is devoted to the future release of the animated cartoon "Mavka. Forest Song" (2020). Thus, the articles scrutinizes the peculiarities of the retranslation by conducting a comparative translation analysis of its text with the earlier English (1950) and German (2006) versions, which were done by Percival Cundy and Irene Katschaniuk-Spiech respectively.
\end{abstract}

Keywords: retranslation, reduction, domestication, foreignization, metaphor, simile.

Retranslations have always been an indispensable component of literary work's existence. Different factors contribute to the creation of new translations. Retranslations of works by Ukrainian authors are rare literary events due to the limited number of L2 speakers of Ukrainian. However, some Ukrainian classics such as the play "Forest Song" by Lesya Ukrainka are gaining more publicity through audiovisual projects, international book fairs etc. and thus become sources for new translations.

Written in 1911, a play "Forest Song" by Lesya Ukrainka is considered to be one of the finest pieces of Ukrainian classical literature. Although, Ukrainian literature in general didn't gain a large audience in Western European countries, Lesya Ukrainka was among a few Ukrainian authors, such as Ivan Franko and Olka Kobylianska, whose works were translated into such European languages as English or German. In fact, some texts were translated and published in Lesya Ukrainka's lifetime as well as by herself. The writer had a fluency in German, French, Polish etc. As K. Koskinen and O. Paloposki point out "[...] retranslation is a result of shifting needs and changing perceptions" [2, p.23]. Thus, with the upcoming animation feature "Mavka. The Forest Song.", which is set to be released in 2020, the need arose to revisit the existing English text (tr. by P. Cundy, 1950) of the drama-fairy tale. Therefore, in 2018 a new translation of the play was published by "Publishing Book House Kiev". The book is in two languages - in Ukrainian and English and the translation was performed by Virlana Tkacz and Wanda Phipps. In English this work was first published by "New York: Bookman Associates" in 1950 with translation done by Percival Cundy (electronic reprint - 2005). Whereas in German it appeared in 1931 ("Staatsverlag Kunst und Literatur") in translation by E. Bermann. The latest version of German translation was published in 2006 by National Ivan Franko university of Lviv Publishing House. The translation was done by a renown germanist Irena Katschaniuk-Spiech. In this article we aim to scrutinize the latest translations of one of the masterpieces of Ukrainian classical literature in terms of retranslations and previous translations dynamic.

Retranslations have always been a controversial issue in translation studies. The French translation scholar Antoine Berman with his belief in an inherent "failure" of all translations inspired the development of the "retranslation hypothesis" by K. Koskinen and O. Paloposki in 2003, according to which "retranslations mark a return to the source text, after an alleged assimilation carried out by first translations" [2, p.21]. Thus, retranslation hypothesis offered a source-oriented approach when considering the motives of the new translations creation. Before that, in 1999 an Israeli translation scholar Gideon Toury suggested a target-oriented approach, stating that "[...] retranslations set out to overcome a deficiency or fill a gap in the target system and to bring in something that was not there before" [1, p. 255]. This approach has gained a lot of support. For example, the entry on "Retranslation" in Routledge Encyclopedia of Translation Studies (2008), which was written by Sehnar Tahir Gürcaglar, is concluded by such a statement: "retranslation is a function of the dynamics of the target context, rather than a response to any inherent properties of the source text" [1, p.236], which is clearly opposes the thought that retranslations " [...] tend to favour a more literal rendering of the original than first translations" by I. Vanderschelden [6, p.1155]. In fact, the debate on retranslation and its value goes far back then XXI and XX centuries. For instance, an American translation scholar Lawrence Venuti in his renown work "The Translator's Invisibility: A history of translation" (1995) illustrates the foreignizing and domestication binarism by examples of retranslations done in England and France in the late $16^{\text {th }}$ and $17^{\text {th }}$ centuries, considering different cases of Virgil's Aeneid retranslations (by Denham, Sir Thomas Wroth) and how their appearance influenced the popularization of the so-called "free method" [7, p. 50], that is a target-oriented approach. Therefore, in examining retranslations of Ukrainian classical work "Forest song" we maintain our focus at detecting the dynamics of approaches to creation new texts in English and German.

Since the play "Forest Song" is also a drama and a fairy tale, it is full of folklore elements in the form of different mystical creatures (mermaids, dwarfs, spirits etc.), which inhabit the forest and are acknowledged by all the people who live near it. The language of the play is full of colors so that the reader would immerse in the universe of nature and its miracles. Thus, the abundance of metaphors, epithets, simili etc. in both characters' lines and narrator's descriptions have a critical role in creating the authentic experience of the readers' of the original. Nev- 
ertheless, the most common translation procedure, used in the most recent translation (2018) of the play is reduction:

1. Перелесник - гарний хлопець у червоній одежі, 3 червонястим, буйно розвіяним, як вітер, волоссям, 3 чорними бровами, з блискучими очима. [5, p.35]

1.1. Spark, a handsome young man in red with reddish hair and sparkling eyes comes dashing out of the forest. $[5, \mathrm{p} .165]$

1.2. Will-o'-the-Wisp, a handsome youth, dressed in red, with a shock of reddish hair blown about by wind [3, p.191]

2. Ох, торішне літо так давно минуло!

Що тоді співало, те взимі заснуло.

Я вже й не згадаю! [5, p.38]

2.1. Last summer was long ago! [5, p.167]

2.2. Of last year's summer I no memory keep.

What was sung then died out in winter's sleep;

No memory it provokes. [3, p.193]

The original narrator's description (example 1) of one of the play characters' appearance is only partially rendered in both the new translation (reddish hair and sparkling eyes) and the previous one (example 1.2.). Each one of them lacks at least one of the features - either brows description (example 1.1.) or eyes and brows (example 1.2.). Such a reduction doesn't fully assist in creating an original image of the character in the source text.

Examples 2.1. and 2.2. illustrate the further discrepancy in treating the poetic imagery of the original by translator. The metaphor from the example 2 is preserved in the 1950 translation by P. Cundy, whereas it is fully reducted in the latest retranslation by V. Tkacz and W. Phipps as we see in example 2.1. The following tendency to reduction can be observed from further examples:

3. Лукаш
Ти бігла?
Мавка
Як білиця.
Лукаш
Втікала?
Мавка
Так. [5, p.46]
3.1. Luke
Are you running from someone?
Mavka
Yes. [5, p.175]
3.2. Lukash
You were running?
Mavka
Like a hare.
Lukash
You were fleeting?
Mavka
Yes. [3, p. 200]
3.3. Lukasch
Bist du gelaufen?
Mavka
Wie ein Wiesel.
Lukasch
Bist du geflüchtet?
Mavka
Ja! [4, p.83]
Mavka ist he protagonist of the play, the spirit of the
rest, a mystical creature somewhat similar to a mermaid in other mythologies, however, she doesn't live in water. She is depicted by Lesya Ukrainka as an embodiment of gentleness, volatility and innocence. Thus, the character's language is the most poetic in the play. Probably that was one of the author's tools of showing the reader the spiritual beauty and naivety of Mavka. Therefore, the reduction of the dialog between her and Lukash (example 3.1.) in the latest retranslation deprives the English reader of experiencing the subtlety of the main character. In 1950 English translation the simile Mavka used to describe her condition is preserved the same way as in the latest German retranslation (example 3.3.) by I. KatschaniukSpiech, which certainly helps preserving the romantic image of Mavka. It is also worth noting that the name of Mavka's love interest Lukash was transliterated in the earlier English translation as well as in the newest German retranslation (Lukasch). However, in the 2018 retranslation the character's name is translated into English - Luke. One can't help avoiding the allusion/ association with Luke from the Star War trilogy. Perhaps that effect was intended in terms of propagating the future animation feature "Mavka. The Forest Song". In any case, the 2018 retranslation as opposed to 1950 English or even 2006 German retranslations is inclined the most to foreignization. This assumption is confirmed by more examples:

4. Місячне світло починає ходити по лісі, сmелеться по галяві і закрадається під березу. В лісі озиваються співи солов'їні і всі голоси весняної ночі. [5, p.47]

4.1. The moon lights up the forest. Nightingales sing out to each other in the forest, as do the other night birds [5, p.176]

4.2. The moonlight creeps on, covering the forest. It spreads all over the glade and steals under the birch. From the forest the song of the nightingale and all the voices of a night in spring are heard. [3, p. 200-201]

4.3. Das Mondlicht wandert über den Wald, senkt sich auf die Lichtung, und zieht dann unter die Birke. Vom Wald her hört man die Nachtigall singen und mit ihr erklingen alle Stimmen einer Frühlingsnacht. [4, p. 85]

5. Цить! Хай говорить серце... Невиразно воно говорить, як весняна нічка. [5, p.50]

5.1. Hush! Let your heart speak... [5, p.178]

5.2. No, hush! I want to hear your heart speak loud.

It talks, but faintly, like the nights in spring. [3, p.203]

5.3. Sei ruhig! Höre zu. Lass das Herz sprechen...

Es spricht undeutlich, wie die Frühlingsnacht. [4, p.89]

6. Як цар морський покличе - треба слухать.

На те с служба, - сам здоровий знасш. [5, p.14]

6.1. When the Sea King calls - I listen [5, p.143]

The personification of the moon light as well as the metaphor (голоси весняної ночі - voices of the spring night) in the narrator's voice in the original text (example 4 , italics) is absent in retranslation of 2018. Both the personification and the metaphor were rendered in earlier English translation as well as German by using calque. The preserving of the imagery assists in establishing the mystically romantic atmosphere of the work in general, its lack simplifies the text in the target language, makes it more standardized than it is in original. Thus, the reduction of lines in the example 6.1. also deprives the target 
text of all the subtle nuances of imagery as well as character traits since the protagonist is clearly giving a cue to his special since of responsibility (That's what the service is about, as you well know yourself - literal translation). In the translation though the readers just see the obeying nature of the character, which can be perceived as a certain kind of cowardness and insecurity. Therefore, reduction can have a harmful impact on original character perception and thus on the perception of the narrative as whole.

In the example 5.1. we observe the reduction of the simile (the human heart is being compared to spring night in the original), whereas P. Cundy and I. KatschaniukSpiech utilize calque for rendering the image of simile in English (example 5.2.) and German (example 5.3.) texts respectively.

\section{7. Притулись до мене.}

Я дужий - здержу, ще й обороню. [5, p.47]

7. 1. Come here. I'll protect you. [5, p.176]

7.2. Then lean on me.

I'm strong...I'll hold you and will you defend. [3, p.200]

\subsection{Lehn dich an mich.}

Ich bin stark - gebe dir Halt und Sturz. [4, p.85]

8. Ти чуєш, як солов'ї весільним співом дзвонять? [5, p.48]

8.1. Do you hear the nightingales' song? [5, p.177]

8.2. Do you not hear the nightingale singing the marriage song? [3, p.201]

8.3. Hörst du nicht, wie die Nachtigallen Hochzeitslieder singen? [4, p.87]

The examples above illustrate the reduction of lines said by the mail protagonists of the play - Lukash and Mavka. Lukash is offering his love interest - Mavka protection by bragging about his physical strength and willingness to protect her. In retranslation of 2018 the lines of Lukash are reducted into a shorter promise of protection (example 7.1.). The epithet "wedding singing by nightingales" (example 8), which Mavka uses as a hint at wanting to become Lukash's wife is also reducted in the English rendering of her lines (example 8.1.). In translation of 1950 the characteristic feature (being strong) as well as psychological element at play (a man bragging about his strength to a woman he likes; a woman showing her willingness or desire to have a common future) are preserved by literal translation. German rendering of 2006 also doesn't omit any of the main character's lines. Therefore, only the latest retranslation uses reduction most often in comparison to other translations, which results in a rather simplistic representation of the play in general.

In conclusion, it is worth stating that retranslations of any kind are a very valuable event in the history of any literature or any literary work since they give it an opportunity to attract more/ new audience and galvanize attention to its artistic value. In the given article, we have considered the recently published retranslation (2018) of the Ukrainian classical work "Mavka. The Forest Song" by Lesya Ukrainka, its 1950 translation into English by Percival Cundy as well as its German retranslation (2006) by I. Katschaniuk-Spiech. The results of the comparative translational analysis show that the latest retranslation in English demonstrates reduction to be the most commonly used translation procedure, which deprives the play of its original poetic imagery and can create a potentially simplistic perception of the literary work by target culture readers. Thus, the newest retranslation of one of the masterpieces of Ukrainian classical literature proves to be distanced from the source text in aspiration to make the work more accessible to a wider readership.

\section{REFERENCES}

1. Gürcaglar S. Retranslation/S. Gürcaglar // Routledge Encyclopedia of Translation Studies (edited by M. Baker, G. Saldanha). - London\&New York: Routledge, 2008. - P.233-236;

2. Koskinen Kaisa, Paloposki Outi. Retranslations in the Age of Digital Reproduction // Kaisa Koskinen, Outi Paloposki. 2003. - p. 19-38. - https:// www.researchgate.net/publication/ 268197658_Retranslations_in_the_Age_of_Digital_Reprodu ction

3. Spirit of Flame: A Collection of the Works of Lesya Ukrainka. Translated by Percival Cundy. New York: Bookman Associates, 1950. - P. 169-260.;

4. Ukrajinka Lessja. Das Waldlied. Feerie in drei Akten/Lessja Ukrajinka; ins Deutsche übertragen von Irena Katschaniuk-
Spiech. - Lwiw: Verlagszentrum der Nationalen IwanFranko-Universität Lwiw, 2006. - 224p.;

5. Ukrainka Lesya. Mavka. The Forest Song/Lesya Ukrainka; tr. into English by V. Tkacz and W. Phipps. - Publishing Book House Kiev, 2018. - 256p.

6. Vanderschelden Isabelle. Re-translation/Isabelle Vanderschelden // Encyclopedia of Literary Translation into English (editor Olive Classe). - London, Chicago: Fitzroy Dearborn publishers. - Vol 2 (M-Z). - 2000. - P. 1154-1155.

7. Venuti Lawrence. The Translator's Invisibility: A history of translation. Lawrence Venuti. - Routledge: London, 1995. $353 \mathrm{p}$. 